\title{
A Conceptual Model of Literature Review for Family Takaful (Islamic Life Insurance) Demand in Malaysia
}

\author{
Juliana Arifin ${ }^{1}$, Ahmad Shukri Yazid ${ }^{1} \&$ Zunaidah Sulong $^{1}$ \\ ${ }^{1}$ Faculty of Business Management and Accountancy, Universiti Sultan Zainal Abidin, Gong Badak Campus, \\ Terengganu, Malaysia \\ Correspondence: Ahmad Shukri Yazid, Faculty of Business Management and Accountancy, Universiti Sultan \\ Zainal Abidin, Gong Badak Campus, 21300 Kuala Terengganu, Terengganu, Malaysia. Tel: 60-9-668-8300. \\ E-mail: shukri@unisza.edu.my
}

Received: October 30, 2012

Accepted: February 6, 2013

Online Published: February 25, 2013

doi:10.5539/ibr.v6n3p210

URL: http://dx.doi.org/10.5539/ibr.v6n3p210

\begin{abstract}
The growing significance of takaful industry (Islamic insurance) in Malaysia is expected to foster sustainable economic growth in Malaysia. Further to this, Malaysia is recorded to be the major player and one of the fastest takaful growth in Southeast Asia. As such, family takaful (Islamic life insurance) segment must be competitive and innovative to increase market penetration and compete with their conventional counterparts. This paper aims to propose a simple yet comprehensive conceptual model by identifying the main determinants that drive family takaful demand in Malaysia. An extensive review of literature available has been carried out to achieve the purpose. Several critical factors namely, agency system (al-wakalah), reputation of takaful operators, products and services, marketing and advertising of takaful products, are found to be the main determinants for family takaful demand.
\end{abstract}

Keywords: family takaful, Islamic life insurance, al-wakalah, Malaysia

\section{Introduction}

Insurance as practised in the conventional financial system refers to a financial protection system that serves as a risk management strategy or tool, to reduce risk uncertainty and provides a planned financing technique that distribute losses. Whereas, takaful system (Islamic insurance) is known as a concept of mutual cooperation (ta'awun) and donation (tabarru'), where the risk is shared collectively and voluntarily by the group of participants to guarantee mutual protection of the members (Dusuki, 2011; Redzuan et al., 2009). The takaful term is derived from the Arabic word kafala, which mean 'joint guarantee' or 'guaranteeing each other' which also explained as a group of individuals that guarantees each other against potential loss or damage faced by anyone of them (see, Ahmad Musadik, 2010; Yusof, 2009).

Section 2 of the Malaysian takaful Act 1984 defines takaful as 'a scheme based on the brotherhood, solidarity and mutual assistance to the participants in case of need whereby the participants mutually agree to contribute or donate for that purpose'. Takaful also can be referred to as a financial transaction of a mutual co-operation between two parties towards providing a financial security for one of them against any misfortune (Ma'sum Billah, 2003). Therefore, it can be said that takaful ta'awuni (Islamic co-operative insurance) is not a contract of buying or selling, where a party offers and sells protection and other party accepts and buys the service at a certain cost or price. Rather, it is an arrangement whereby a group of individuals each pay a fixed amount of money, and compensation for the losses of members of the group are paid out of the total sum. Thus, it reflects a sense of brotherhood and solidarity amongst the participants who are willing to help and assist one another in times of difficulty and need. Accordingly, the holy Qur'an, in verse 5:2, mentioned that: “... help you one another in Al-Birr and At-Taqwa (virtue, righteousness and piety); but do not help one another in sin and transgression ...".

In recent years, the takaful industry has become more diverse internationally and locally as there has been tremendous increase in the number of takaful operators operating worldwide as well as in Malaysia. For instance, the takaful market shows strong growth in countries such as Malaysia, Indonesia, Singapore and Brunei. Meanwhile, in the Middle East, the takaful industry concentrates in Saudi Arabia, Bahrain, Iran, Qatar and Iran with new takaful operations opening up in Egypt, UAE and Kuwait. This tremendous increase of takaful operators in Malaysia open great opportunities for expansion in takaful market share and increased penetration. 
Abdul Hamid and Ab. Rahman (2011) have argued that the role of agency force is important as intermediaries between customers and takaful operators which can contribute to the high performance for the takaful industry in Malaysia. The industry is in good position to seize the enormous opportunities from the estimated 1.5 billion Muslims around the world whom are currently underserved by the insurance industry (Abd. Kadir, 2011).

There are two types of takaful, namely general takaful and family takaful. At one hand, among significant features of general takaful are short-term policy, contributions paid by participants are credited into the general takaful fund, tabarru' as the core element, no savings element and can be categorised into motor and non-motor takaful. On the other, family takaful typically is long-term policy in nature, loosely comparable to conventional life insurance. Participants aim at saving for their long-term needs, for example their children's education, their pension and compensation for dependants in the event of death and disability, amongst others. Family takaful also covers two funds that are, savings (participant account) and investment elements (participant's special account or tabarru').

This paper focuses on two main objectives. First, to identify critical factors that determine the family takaful demand. Second, to develop a conceptual model for determinants of family takaful demand in the context of Malaysian study.

The remainder of the paper is structured into six sections as follows: Section 2 justifies the problem statement of the study. Section 3 describes research methodology. Section 4 provides an extensive review of literature on determinants of family takaful demand. Then, a conceptual model on family takaful demand is proposed in Section 5. Finally, Section 6 concludes the discussion.

\section{Problem Statement}

The global takaful industry has witnessed impressive growth, particularly over the last five years. However, the performance of Malaysia takaful industry is still lags far behind in terms of total insurance market penetration and share. According to Takaful Ikhlas President and Chief Executive Officer Datuk Syed Moheeb Syed Kamarulzaman (2010), Malaysia's penetration rate for takaful industry is around 10 percent, compared with overall conventional insurance industry which is stood at 40 percent. It has been highlighted that the primary target in takaful industry is the Muslim segment as the Muslim population in Malaysia comprises more than 60 percent of the total population (OSK Research Report, 2012). This fact represents a large untapped potential market for takaful industry in Malaysia.

The Malaysian government entrusted Bank Negara Malaysia (Central Bank of Malaysia) to play an important role in promoting takaful businesses by providing better financial infrastructure. Hence, the takaful industry in Malaysia has been undergoing a steady growth and facing the rapid changes over the last five years. According to Bank Negara Malaysia Report (2011) the growth of this industry can be seen through its business performance. As shown in Table 1, the total of takaful business performance in term of gross contributions are increased from RM2,255 millions in 2007 to RM4,295 millions in 2011. For family takaful business, the gross contribution also increased from year to year. Similarly for general takaful business, the gross contributiosn are increased albeit only at a slower pace which was from RM768 millions in 2007 to RM1,600 millions in 2011 compared with performance of family takaful business. In short, takaful industry in Malaysia has strongly contributed by family takaful business compared with the general takaful business.

Table 1. Takaful business performance from years 2007 to 2011

\begin{tabular}{llll}
\hline Category & Year & RM (million) & Growth (\%) \\
\hline FT & 2007 & 1,487 & 17.4 \\
GT & & 768 & 7.0 \\
Total & & 2,255 & 24.4 \\
\hline FT & 2008 & 1,980 & 33.2 \\
GT & & 874 & 13.8 \\
Total & & 2,854 & 47 \\
\hline FT & 2009 & 2,178 & 10.0 \\
GT & & 1,054 & 20.6 \\
Total & 3,232 & 30.6 \\
\hline FT & 2010 & 2,587 & 18.8 \\
GT & & 1,346 & 27.7 \\
Total & & 3,933 & 46.5 \\
\hline FT & 2011 & 2,695 & 4.2 \\
GT & & 1,600 & 18.9 \\
Total & 4,295 & 23.1 \\
\hline
\end{tabular}

Source: Bank Negara Malaysia Report (2011).

Notes: $\mathrm{FT}=$ Family Takaful, GT $=$ General Takaful. 
Ernst \& Young World Takaful Report (2011) Malaysia shows a strong takaful growth among Southeast Asia countries. It is reported that there is a large untapped market that still exists with only 54 percent of the population having a life insurance or family takaful policies in 2010 (Abd. Kadir, 2011). By focusing into family takaful market, the family takaful penetration rate is merely 10 percent of the population in 2010 (OSK Research Report, 2012). Therefore, it can be argued that family takaful market is facing a lower market penetration compared to the conventional life insurance market in Malaysia. Many incentives are given by the Malaysian government in promoting family takaful such personal tax relief for takaful contribution from RM5,000 to RM6,000. In addition, new parliamentary initiatives from government such as the New Economic Model (NEM), Economic Transformation Program (ETP) and the Tenth Malaysian Plan would lead to the growth in demand for takaful products and services. Therefore, it is important to highlight why family takaful penetration is still low and what are the factors that influence the family takaful demand.

\section{Research Methodology}

This paper uses qualitative approach by systematically review all relevant literature from various databases. To have a clear and precise guidance in reviewing the literature, two research questions are developed. First, what are the critical factors for the family takaful demand? Second, what is the proposed conceptual model for the determinants of family takaful demand. In searching for literature only articles in established journals are reviewed including Proquest, EBSCO, Web of Science - Social Citations Index and Business Source Premier. A literature search produced a total of more than 100 articles, of which 36 are randomly picked for detailed review.

\section{Literature Review}

\subsection{Empirical Evidence: Factors Related to Family Takaful Demand}

It is worth noted that issues relating to takaful have always been discussed but little empirical study on the determinants of family takaful demand has been conducted. Obviously, from the previous literature, there is very limited research focusing on family takaful. Thus, it can be concluded that many researchers may have less interest to explore issues related family takaful as compared to the conventional life insurance. The main reason could be family takaful is still at its infancy stage. Among earlier study on family takaful is conducted Redzuan et al. (2009) by using economic factors as determinants of family takaful demand. Their study aim to identify the driving force of family takaful consumption in Malaysia. The main finding of the study indicated that income per capita is a robust predictor of family takaful demand, while long term interest rate and composite stock index have significant relationship with family takaful demand. A study by Yusoff (2009) also explored the determinants of the demand for family takaful in Malaysia. In this study, they investigated both of the economic and socio-demographic factors in order to determine the consumption of family takaful which is slightly difference with study of Redzuan et al. (2009) in terms of variables used. Among demographic factors, this study indicated that income, Islamic banking development, education, dependency ratio, and Muslim population factors are positively related to family takaful demand. On the other hand, among economic factors, it is found that inflation, real interest rate, financial development and life expectancy appear to be the significant factors that influence the family takaful demand in Malaysia.

Meanwhile, Mohd Nor (2010) examined the awareness and ownership of family takaful plan among Muslim community in Kuala Lumpur. His study is attempted to obtain a deeper understanding of the relationship between levels of awareness and the purchase of family takaful plan. The results of the study indicate that the level of awareness is very high. It was identified that the level of awareness has significant positive relationship with respondents' ownership of family takaful plan. Whereas, a study by Omar (2010) has found that the perception of customers of Prudential BSN Family takaful and Prudential Life Insurance that takaful plan would guarantee savings and protection to them. Besides, the study also found that from customers' perception that Shariah Supervisory Council plays an important role in ensuring the implementation of takaful in Malaysia.

In addition to this literature, the studies of Islamic finance as well as Islamic banking which related to the issue were also being reviewed to understand the factors on selection of Islamic institutions which can be applied into this current study on determinants of family takaful demand. For example, a survey by Gait and Worthington (2008) have found that religion is the main factor considered by customers in Islamic finance, although further pricing, bank reputation and quality of service are also very important criteria for bank customers. This is supported by Al-Ajmi et al. (2009) who revealed that Islamic religious belief and social responsibility are the two most important factors while cost benefit is the third most important factor considered in determine bank selection. Adnan (2010) has examined the choice determinants of Islamic banking institution among Muslims in Terengganu. This survey has found eight determinants factors consists of halal (permitted) and haram (forbidden) consideration, quality consumption, maslahah return, consumption according to priority, reputation 
and recommendation, characteristics of products and services, convenience, and marketing and advertising. He also has examined the relationship of these determinants with the demographic and religious adherence factors. Amin et al. (2011) investigated the effects of the following factors: attitude; social influence; religious obligation; government support; and pricing, on the intention to use Islamic personal financing. The study has found that only three determinants to be significant in influencing the intention to use Islamic personal financing namely attitude, social influence, and pricing of Islamic personal financing. Whereas, religious obligation and government support are found to be insignificant predictors.

\subsection{Determinants of Family Takaful Demand}

Even though there are substantial study conducted on takaful, but research on family takaful is still very few compared with conventional life insurance. As mentioned earlier, prior studies have attempted to examine conventional life insurance demand are based on demographic factors (for example, Hammond et al., 1967; Duker, 1969; Headen \& Lee, 1974; Burnett \& Palmer, 1984; Truet \& Truet, 1990; Showers \& Shotick, 1994; Gandolfi \& Miners, 1996; Lin \& Grace, 2007; Yusof et al., 2009) and economic variables (for example, Neumann, 1969; Cargill \& Troxel, 1979; Babble, 1981, 1985; Lim \& Haberman, 2004; Ching et al., 2010). These economic factors also are employed in the study of family takaful demand (Redzuan et al., 2009; Sherif, 2009). However, the present paper focuses on the determinant factors of family takaful demand among Muslim customers in Malaysia by examining various factors to provide a better understanding of how and why family takaful purchases are made. Since the available relevant literature related to family takaful is very scarce, we also rely on the literature related to Islamic finance and banking. Finally, we are able to conclude that there are four main critical factors that could be significantly contribute to the family takaful demand.

\subsubsection{The Agency System (Al-Wakalah)}

The agency system or al-wakalah in the Arabic word is commonly used by takaful operators in distributing family takaful products which is approved by Shariah (Islamic Jurisprudence). According to Bashir et al. (2011), al-wakalah model is a form of relationship between the takaful operator and participant. In this case, takaful operator acts as the participant's agent and will be paid fees for the services provided. The fees are charged as a fixed amount or percentage, or based on the agreed ratio from the investment profits (Abdul Hamid et al., 2010; Bashir et al., 2011; Htay \& Zaharin, 2012). A study by Annuar (2004) has revealed that customers prefer the agency system (al-wakalah) in dealing with a takaful company. It is found that customers prefer to choose agency system as it generates greater benefits to takaful operators while not causing any harm to customers (Annuar, 2004; Annuar et al., 2001). However, Hamid and Othman (2009) have shown that most of the respondents do not know or understand about the new concept of al-wakalah (agent) which contribute to less participant in takaful.

\subsubsection{Reputation and Recommendation}

There are many studies which considered the reputation as one of the factors that contribute to the selection of Islamic financial instituitions such as in finance, banking, as well as in insurance (Haron et al., 1994; Gerrard \& Cunningham, 1997; Naser et al., 1999; Al-Ajmi et al., 2009; Mansour et al., 2010; Bashir et al., 2011; among others). Various studies (for example, Naser et al., 1999; Almossawi, 2001; Dusuki \& Abdullah, 2007; Gait \& Worthington, 2008; Mansour et al., 2010) have affirmed that the reputation as of the important contributors in the selection of Islamic banking among customers. It is in line with a takaful study, which found that majority of respondents chose reputation as their reason for choosing takaful operator (Bashir et al., 2011). Meanwhile, the recommendation made by families or friends also contribute in selecting Islamic financial system (Haron et al., 1994; Gerrard \& Cunningham, 1997; Metawa \& Almossawi, 1998; Naser et al., 1999). In addition, Mansor (2004) has found that one of the reasons why policyholders choose to join family takaful is because of the recommendation of their families, friends and relatives. Hashim (2006) also has reported that most of their respondents agreed that they know about family takaful from their family and friends.

\subsubsection{Product and Services}

There are number of studies focuses on both customers' awareness and satisfaction of product and services in Islamic financial system (see, Naser et al., 1999; Ahmad \& Haron, 2002; Bley \& Kuehn, 2003; Dusuki \& Abdullah, 2007; Al-Ajmi et al., Adnan, 2010; Mansour et al., 2010). While, a few of studies have focused only on the consumers preferences to Islamic banking products (see, Gerrard \& Cunningham, 1997; Metawa \& Almoswawi, 1998; Bley \& Kuehn, 2003; Rammal \& Zurbruegg, 2006). Meanwhile, some of the studies focused on consumers' attitude, perception and knowledge of Islamic financial products (Yusof \& Shamsuddin, 2003; Gait \& Worthington, 2008). These studies have indicated that majority of customers prefer to choose products and services that are conform to Shariah (Naser et al., 1999; Ahmad \& Haron, 2002; Al-Ajmi et al., 2009; 
Mansour et al., 2010; Rustam et al., 2011). In addition, a study by Bashir et al. (2011) has documented that easy to understand product is one of the critical reasons for choosing takaful operator.

\subsubsection{Marketing and Advertising}

There have been some research on marketing and advertising which can influence customers' buying behaviour (Abideen \& Saleem, 2011; Gilaninia \& Ghashlagh, 2012) and the selection of Islamic banks (Haron et al., 1994; Gerrard \& Cunningham, 1997; Hassan et al., 2008; Haque, 2010; Adnan, 2010; Hakim et al., 2011). Similarly, other studies have indicated that there is significant relationship between effective marketing and advertising and the consumers' buying behaviour (Abideen \& Saleem, 2011; Gilaninia \& Ghashlagh, 2012). Moreover, Haron et al. (1994), Gerrard and Cunningham (1997), and Adnan (2010) have argued that marketing and advertising influence customers selection of Islamic banks.

\section{Proposed Conceptual Framework}

Based on the reviewed of relevant literature available, a conceptual model for determinants of family takaful demand is developed. This study suggests that several factors such as the agency system (al-wakalah), reputation and recommendation, products and services, marketing and advertising are considered important factors that determine family takaful demand. The proposed model for this study is presented in Figure 1 as follows:

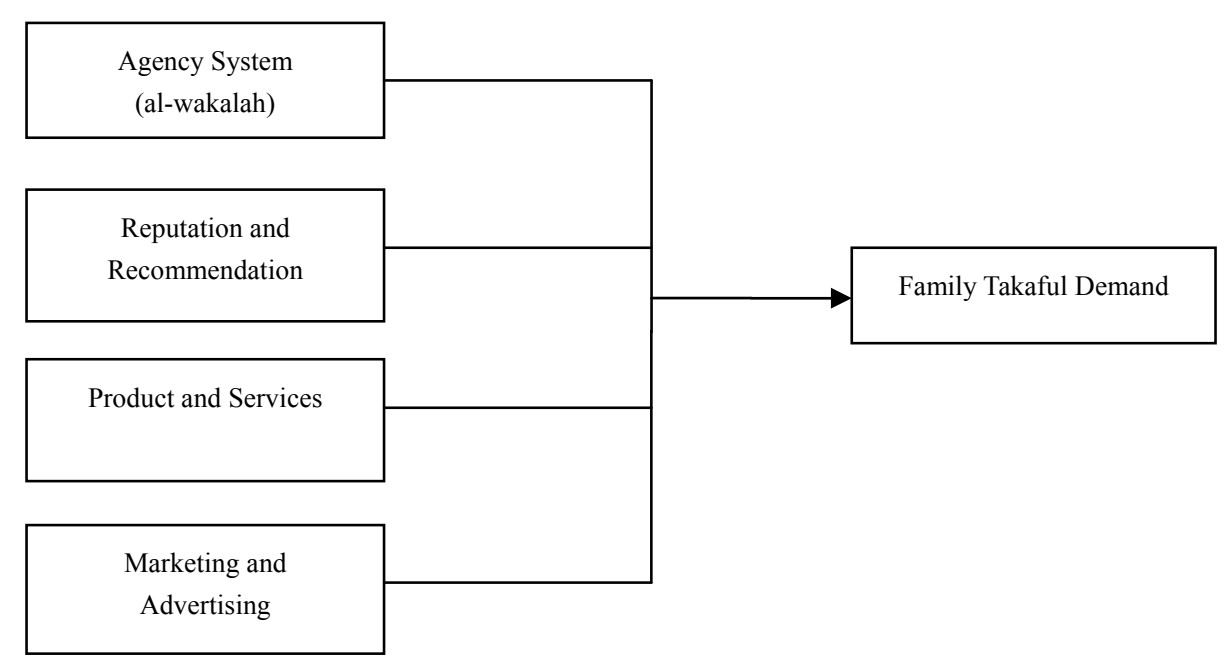

Figure 1. A proposed conceptual model for determinants of family takaful demand

From the above, one can hypothesize that:

- There are positive relationships between variables namely agency system (al-wakalah), reputation and recommendation, products and services, marketing and advertising with family takaful demand.

Hence, future study seeks to test the proposed conceptual model for family takaful demand particularly in the context of Malaysia.

\section{Conclusion}

This paper seeks to come up with a conceptual model by identifying a set of determining factors that contribute to the demand for family takaful. From the extensive review of relevant literature available, there are four factors that could possibly influence family takaful demand. Further empirical study is therefore needed to examine whether all of these factors contribute significantly to the family takaful demand. We expect a positive relationship between the proposed critical factors that determine the demand for family takaful. Limitation of the present study is that we have confined ourselves to published articles, both academic or practioner, which are available to us from the four chosen databases. There maybe articles not brought to our attention, hence, interpretation of the proposed model in this study on family takaful demand in Malaysia may be somewhat limited.

\section{References}

Abd. Kadir, M. R. (2011). Promoting the Takaful Industry in Malaysia. Central Bank of Malaysia. Retrieved from http://www.bis.org/review/r110405d.pdf

Abdul Hamid, M., \& Nik Ab. Rahman, N. (2011). Commitment and Performance: A Case of Takaful (Islamic 
Insurance) Representatives in Malaysia. Australian Journal of Basic and Applied Sciences, 5(10), 777-785.

Abdul Hamid, M., \& Othman, M. S. (2009). A Study on the Level of Knowledge and Understanding among Muslims towards the Concepts, Arabic and Shariah Terms in Islamic Insurance (Takaful). European Journal of Social Sciences, 10(3), 468-478.

Abdul Hamid, M., Yaa'kub, N. I., \& Ab. Rahman, N. M. (2010). Operational Issues and Shariah Harmonisation Towards the Development of Corporate Takaful Business: Conventional Debt Financing and Reinsurance Mechanism. Jurnal Muamalat, 3, 139-155.

Abideen, Z. U., \& Saleem, S. (2011). Effective Advertising and its Influence on Consumer Buying Behavior. European Journal of Business and Management, 3(3), 55-65.

Adnan, A. A. (2010). Penentu Pemilihan Institusi Perbankan Islam Dalam Kalangan Muslim Di Terengganu. (Unpublished Ph.D Thesis). Universiti Sains Malaysia.

Ahmad Musadik, S. H. S. (2010). Factors Influencing the Tendency to Subscribe with Takaful Among Martial Arts Practitioners. (Unpublished Master Thesis). Universiti Utara Malaysia.

Ahmed, N., \& Haron, S. (2002). Perception of Malaysian Corporate Customers towards Islamic Banking Products and Services. International Journal of Islamic Financial Services, 3(4), 1-16.

Al-Ajmi, J., Hussain, H. A., \& Al-Saleh, N. (2009). Clients of Conventional and Islamic Banks in Bahrain: How They Choose Which Bank to Patronize. International Journal of Social Economics, 36(11), 1086-1112. http://dx.doi.org/10.1108/03068290910992642

Amin, H., Rahman, A. R. A., \& Hwa, A. M. C. (2011). Determinants of Customers' Intention to Use Islamic Personal Financing: The case of Malaysian Islamic banks. Journal of Islamic Accounting and Business Research, 2(1), 22-42. http://dx.doi.org/10.1108/17590811111129490

Annuar, H. A. (2004). Al-Wakalah and Customers' Preferences towards It: A Case Study of Two Takaful Companies in Malaysia. The American Journal of Islamic Social Sciences, 22(1), 29-49.

Annuar, H. A., Rosly, S. A., \& Rashid, H. M. (2004). Al-Wakalah and its Impact on the Growth and Performance of Takaful Companies: A Case of Malaysia. The European Journal of Management and Public Policy, 3(1), 84-119.

Babbel, D. F. (1985). The Price Elasticity of Demand for Whole Life Insurance. Journal of Finance, 40(1), 225-239. http://dx.doi.org/10.2307/2328057

Bank Negara Malaysia. (2011). The Central Bank and the Financial System in Malaysia: Kuala Lumpur.

Bashir, M. S., Mail, N. H. H., \& Abd. Ali, N. J. A. (2011). Consumer Perception on Takaful Business in Brunei Darussalam. International Conference on Management Proceeding, 1144-1163.

Burnett, J. J., \& Palmer, B. A. (1984). Examining Life Insurance Ownership through Demographic and Psychographic Characteristics. Journal of Risk and Insurance, 51, 453-467. http://dx.doi.org/10.2307/252479.

Ching, K. S., Kogid, M., \& Furuoka, F. (2010). Causal Relation between Life Insurance Funds and Economic Growth Evidence from Malaysia. ASEAN Economic Bulletin, 27(2), 185-200. http://dx.doi.org/10.1355/ae27-2c

Duker, J. M. (1969). Expenditures for Life Insurance among Working-Wife Families. Journal of Risk and Insurance, 36(5), 525-533. http://dx.doi.org/10.2307/251159

Dusuki, A. W. (2011). Islamic Financial System - Principles \& Operations. International Shari'ah Research Academic for Islamic Finance (ISRA): Kuala Lumpur.

Dusuki, A. W., \& Abdullah, N. I. (2007). Why Do Malaysian Customers Patronize Islamic Banks? International Journal of Bank Marketing, 25(3), 142-160. http://dx.doi.org/10.1108/02652320710739850

Gait, A., \& Worthington, A. (2008). An Empirical Survey of Individual Consumer, Business Firm and Financial Institution Attitudes towards Islamic Methods of Finance. International Journal of Social Economics, 35(11), 783-808. http://dx.doi.org/10.1108/03068290810905423

Gandolfi, A. S., \& Miners, L. (1998). Gender-based Differences in Life Insurance Ownership. Journal of Risk and Insurance, 63(4), 683. http://dx.doi.org/10.2307/253478

Gerrard, P., \& Cunningham, J. B. (1997). Islamic Banking: A Study in Singapore. International Journal of Bank 
Marketing, 15(6), 204-216. http://dx.doi.org/10.1108/02652329710184433

Gilaninia, S., \& Ghashlagh, B. G. (2012). Relationship Marketing System and Its Impact on Customer Buying Behavior. Journal of Basic and Applied Scientific Research, 2(3), 2473-2479.

Hakim, S. A., Bhatti, O. K., \& Al-Jubari, I. (2011). Advertising of Islamic Banking Products. Annals of Management Research, 1, 60-70.

Haque, A., Ahmed, K., \& Jahan, S. I. (2010). Shariah Observation: Advertising Practices of Bank Muamalat in Malaysia. Journal of Islamic Marketing, 1(1), 70-77. http://dx.doi.org/10.1108/17590831011026240

Haron, S., Ahmad, N., \& Planisek, S. L. (1994). Patronage Factors of Muslim and Customers. International Journal of Bank Marketing, 12(1), 32-40. http://dx.doi.org/10.1108/02652329410049599

Hassan, A., Chachi, A., \& Latiff, S. A. (2008). Islamic Marketing Ethics and Its Impact on Customer Satisfaction in the Islamic Banking Industry. J.KAU: Islamic Economic, 21(1), 23-40.

Htay, S. N. N., \& Zaharin, H. R. (2012). Critical Analysis on the Choice of Takaful (Islamic Insurance) Operating Models in Malaysia. World Journal of Social Sciences, 2(2), 112-127.

Jimin, S. A. (2011). Evolution of the Malaysian Takaful Industry Brief Introduction to Takaful, pp. 1-38.

Lim, C. C., \& Haberman, S. (2001). Macroeconomic Variables and the Demand for Life Insurance in Malaysia. Retrieved form http://www.cass.city.ac.uk/data/assets/pdf/LimHaberman29

Ma'sum Billah, M. (2003). Islamic Insurance (Takaful). Petaling Jaya: Ilmiah Publishers Sdn. Bhd.

Mansour, W., Abdelhamid, M. B., Masood, O., \& Niazi, G. S. K. (2010). Islamic Banking and Customers' Preferences: The Case of the UK. Qualitative Research in Financial Markets, 2(3), 185-199. http://dx.doi.org/10.1108/17554171011091746

Metawa, S. A., \& Almossawi, M. (1998). Banking Behavior of Islamic Bank Customers: Perspectives and

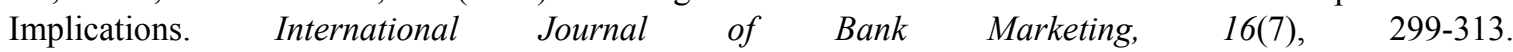
http://dx.doi.org/10.1108/02652329810246028

Naser, K., \& Jamal, A. (1999). Islamic Banking: A Study of Customer Satisfaction and Preferences in Jordan. International Journal of Bank Marketing, 17(3), 135-150. http://dx.doi.org/10.1108/02652329910269275

Neumann, S. (1969). Inflation and Saving through Life Insurance. Journal of Risk and Insurance, 36(5), 567-582. http://dx.doi.org/10.2307/251163

Redzuan, H., Rahman, Z. A., \& Aidid, S. S. H. (2009). Economic Determinants of Family Takaful Consumption: Evidence from Malaysia. International Review of Business Research Papers, 5(5), 193-211.

Rustam, S., Bibi, S., Zaman, K., Rustam, A., \& Haq, Z. U. (2011). Perceptions of Corporate Customers towards Islamic Banking Products and Services in Pakistan. The Romanian Economic Journal, 41, 107-123

Showers, V. E., \& Shotick, J. A. (1994). The Effects of Household Characteristics on Demand for Insurance: A Tobit Analysis. Journal of Risk and Insurance, 61(3), 492-502. http://dx.doi.org/10.2307/253572.

Takaful Annual Report. (2011). Bank Negara Malaysia: Kuala Lumpur.

The World Takaful Report. (2011). Earnst \& Young, pp. 1-70.

Truett, D. B., \& Truett, L. J. (1990). The Demand for Life Insurance in Mexico and the United States: A Comparative Study. Journal of Risk and Insurance, 57(2), 321-328. http://dx.doi.org/10.2307/253306

Yusof, T. O., Gbadamosi, A., \& Hamadu, D. (2009). Attitudes of Nigerians towards Insurance Services: An Empirical Study. African Journal of Accounting, Economics, Finance, and Banking Research, 4(4), 34-46.

Yusoff, M. E., \& Shamsuddin, A. S. (2001). Muslim Consumers Attitude toward Islamic Finance Products in A Non-Muslim Country. Jurnal Kemanusiaan, 94-103. 